\title{
A stingless bee marks the feeding site in addition to the scent path (Scaptotrigona aff. depilis)
}

\author{
Veronika M. SCHMIDT ${ }^{\mathrm{a}}$, Ronaldo ZUCCHI ${ }^{\mathrm{b}}$, Friedrich G. BARTH ${ }^{\mathrm{a} *}$ \\ a University of Vienna, Biocenter, Institute of Zoology, Althanstr. 14, 1090 Wien, Austria \\ b University of São Paulo, FFCLRP, Department of Biology, Avenida Bandeirantes 3900, \\ 14040-901 Ribeirão Preto, SP, Brasil
}

(Received 8 July 2002; revised 20 September 2002; accepted 25 September 2002)

\begin{abstract}
Scaptotrigona depilis uses a scent trail to guide newly recruited bees to a food source. (i) Behavioral experiments show an additional chemical marking at the food source. The bees had to choose between an unused feeder and a feeder, at which their nestmates had fed. 71 to $86 \%$ of the bees chose the used feeder where the foragers had left attractants. The used feeder also attracted bees when it was moved away from its original site to a new site halfway along the scent path or $20 \mathrm{~m}$ beyond it. (ii) The localization of a food source by S. depilis is very precise with regard to both direction and distance. When control feeders were $1.7 \mathrm{~m}, 8.5 \mathrm{~m}$, and $17 \mathrm{~m}$ away from the experimental feeder (at $50 \mathrm{~m}$ from the nest) $97.5-100 \%$ of the recruits chose the experimental feeder where the foragers were feeding. When positioned beyond the used feeder the control feeder remained unvisited. We conclude, that markings left at the used feeder represent particular end point tags and differ from scent path markings.
\end{abstract}

stingless bee / Scaptotrigona / scent marking / recruitment

\section{INTRODUCTION}

The use of chemical signals in stingless bees to scent a trail for the guidance of newly recruited nestmates to a food source was observed in species of the genera Trigona, Scaptotrigona, Cephalotrigona, Geotrigona, and Oxytrigona (Lindauer and Kerr, 1958, 1960; Kerr, 1960; Kerr and Cruz, 1961; Kerr et al., 1963; Blum et al., 1970; Kerr et al., 1981; Johnson, 1987; Kerr, 1994). Species of the genus Scaptotrigona (Apidae, Meliponinae) are surprisingly efficient in scent trail recruitment, when the number of bees recruited to a food source in a given time (Lindauer and Kerr, 1958, 1960; Jarau et al., 2003) and the precision of food source localization (Lindauer and Kerr, 1958; Kerr et al., 1963) are taken as measures. Aiming at a better understanding of the chemical signals used for scent trail marking, the contents of Scaptotrigona's mandibular glands (Luby et al., 1973) and head extracts (Franke et al., 1983) were analyzed. However, no data are available demonstrating the actual use and behavioral relevance of the components identified. The morphology of the mandibular glands, which may play a significant role in scent marking (Lindauer and Kerr, 1958, 1960; Blum et al., 1970), is well known (Nedel, 1960; Cruz-Landim and Akahira, 1966; Cruz-Landim and Ferreira, 1967; CruzLandim and Ferreira, 1968). The mandibular glands are well developed in young bees but

\footnotetext{
* Correspondence and reprints

E-mail: friedrich.g.barth@univie.ac.at
} 
degenerate with age. There is, however, no conclusive evidence as yet that they are indeed used for communication by foraging bees.

Our present knowledge of scent trail marking and following is still based on the experiments by Lindauer and Kerr $(1958,1960)$ and Kerr et al. (1963). According to these studies scent trails are a prerequisite for successful recruitment in Scaptotrigona. The foraging bees land every $2-5 \mathrm{~m}$ on their way back to the nest to secrete the scent marks, which then serve the newcomers (recruited in the nest) as guideposts on their way out to the food source (Lindauer and Kerr, 1958, 1960). The scent marks' source was postulated to be the mandibular glands, because the scent marks smelled like the dissected glands and because the bees ran $3 \mathrm{~mm}$ along the edge of a leaf or stone or blade of grass, rubbing their mandibles on the respective surface while scent marking (Lindauer and Kerr, 1958, 1960).

In contrast with Scaptotrigona, bees of the genus Melipona do not lay scent trails (Lindauer and Kerr, 1958; Nieh and Roubik, 1995; Hrncir et al., 2000). However, scent beacons at the food source have been described for several species (Aguilar and Sommeijer, 1996, 2001; Nieh, 1998). For Melipona seminigra Hrncir et al. (2003) recently demonstrated the chemical marking of the food source itself with attractants secreted at the bees' tarsi.

Here we ask whether scent path laying species mark the feeding site as well. Accordingly, the present study examines (1) whether Scaptotrigona aff. depilis Moure 1942, a species using scent trails to guide recruits to a food source, specifically scent marks the feeding site in a way different from scent path laying, (2) whether feeding site marks remain effective when spatially separated from their original site, and (3) whether feeding site marks specifically tag the end point of a scent path.

\section{MATERIALS AND METHODS}

\subsection{Study site and animals}

All experiments were performed on the USPCampus at Ribeirão Preto, São Paulo, Brazil, between July 2001 and February 2002. We used two colonies of Scaptotrigona aff. depilis

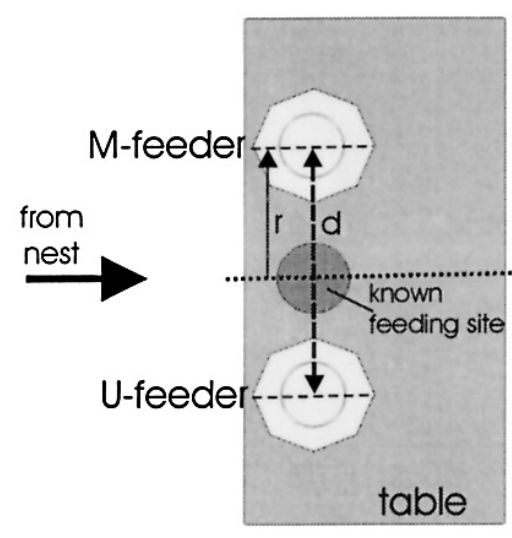

Figure 1. Choice experiments. The bees had to choose between two feeders arranged equidistantly to the previous known feeding site (now without feeder). The two feeders were the M-feeder (marked by foragers when used at the known feeding site) and the U-feeder (unmarked, not used before), whose distance $(d=2 r)$ from each other was $20 \mathrm{~cm}$ and $170 \mathrm{~cm}$, respectively. Table and feeders are not drawn to scale.

(Camargo, personal communication). The colony used for choice experiments and displacement experiments was kept in a wooden nest box inside the laboratory. For localization experiments we used another naturally occurring colony, living in a cavity inside a stonewall.

In all experiments and training phases we used feeders as described in Jarau et al. (2000). The feeders were placed on laboratory stools as feeding tables (height $60 \mathrm{~cm}$, diameter $35 \mathrm{~cm}$ ) except for the choice experiments. All items of the setup were alcohol cleaned (ethanol, 95\%) before each experiment, except the feeders defined as "marked" by the foraging bees. The feeders rested on a vial (height $=35 \mathrm{~mm}$ ) within a petri dish, which was filled with water to ward off ants.

\subsection{Choice experiments to demonstrate whether the feeding site is marked chemically}

Training and foraging phase. We trained several bees to the midline on the front edge of a table (height $75 \mathrm{~cm}$, length $2 \mathrm{~m}$, width $50 \mathrm{~cm}$ ) at a point $18 \mathrm{~m}$ to the South of the bees' nest using $0.75 \mathrm{ML}^{-1}$ unscented sugar water. The bees were allowed to feed ad libitum at this site for at least 45 minutes, after which time the site was defined as "the known feeding site" (Fig. 1). At the end of the training phase we marked four bees with a colored dot, whereas all other bees coming to the feeding 
site were captured using a plastic suction tube. The training feeder was then replaced by an alcohol cleaned feeder containing $0.75 \mathrm{ML}^{-1}, 1.5 \mathrm{ML}^{-1}$, or $3 \mathrm{ML}^{-1}$ unscented sugar water, depending on the test series. The four foragers were now allowed to feed at the clean feeder until together they had completed 20 visits. They were then captured and kept separate from the previously captured bees. The same feeder was now defined as M-feeder (hypothetically assuming that it was marked by the four foragers).

Choice phase. The M-feeder was shifted either to the left or to the right of the known feeding site by distance $r$ along the front edge of the table (Fig. 1). At the same distance $r$ but on the opposite side of the known feeding site we placed an unused, alcohol cleaned, but otherwise identical feeder defined as U-feeder (unmarked). Now the previously captured bees (except the four foragers) were released at the nest's entrance. They continued their search for food at the feeding site already known to them. At their previous feeding site, however, there was no food anymore. Instead the bees had to make a choice between the M-feeder and the U-feeder. The experiment started when the first bee landed on one of the feeders and lasted for 20 minutes. All bees landing at the M-feeder or at the U-feeder were captured. Only those bees were counted which landed when no other bee was at the feeder, to avoid attraction by the feeding bees. The positions of the M-feeder and the U-feeder were exchanged every five minutes in order to avoid side biasing.

For $d=2 r=20 \mathrm{~cm}$ we carried out three test series using $0.75 \mathrm{ML}^{-1}, 1.5 \mathrm{ML}^{-1}$, and $3 \mathrm{ML}^{-1}$ sugar water, respectively. Two test series were performed for $d=170 \mathrm{~cm}$, with $1.5 \mathrm{ML}^{-1}$, and $3 \mathrm{ML}^{-1}$ sugar water, respectively.

Control experiments. The bees had the choice between two unused and alcohol cleaned feeders containing $1.5 \mathrm{ML}^{-1}$ unscented sugar water (otherwise setup identical to that described above) and $20 \mathrm{~cm}$ or $170 \mathrm{~cm}(d)$ apart from each other. All bees landing on the feeders during $20 \mathrm{~min}$ were captured. For the reasons given earlier a bee was only counted, if at the same time no other bee was at the feeder. The position of the two feeders again was exchanged every five minutes. In case of a preference (which was never significant) for one of the two feeders, the "preferred" feeder was defined as A-feeder and the other one as the B-feeder.

\subsection{Experiments to examine whether marks remain effective on displaced feeders}

The bees were trained to a distance of $25 \mathrm{~m}$ or $50 \mathrm{~m}$ from the nest. The training feeder was then replaced by an alcohol cleaned feeder containing $3 \mathrm{ML}^{-1}$ unscented sugar water in order to initiate the bees' free recruitment, where all the bees were allowed to return to the nest and to visit the food source without any interference by the observer for at least $45 \mathrm{~min}$. From then on we defined this feeding site as "the original feeding site". An additional food source was then presented at "the experimental site" offering $3 \mathrm{ML}^{-1}$ unscented sugar water. Furthermore, $3 \mathrm{ML}^{-1}$ sugar water was offered throughout the whole experiment at the original feeding site in order not to endanger the maintenance of the scent path. (i) In the first test series the original feeding site was at $25 \mathrm{~m}$ from the nest. The experimental site was at a distance of only $13 \mathrm{~m}$ from the nest (between the nest and the original feeding site), i.e. halfway along the scent path; (ii) in the second test series the original feeding site was at a distance of $50 \mathrm{~m}$ from the nest. The experimental site was at a distance of $70 \mathrm{~m}$ from the nest, i.e. $20 \mathrm{~m}$ beyond the original feeding site (beyond the scent path).

Experimental procedure. Two feeders were positioned equidistant to the feeding table's midline $(d=20 \mathrm{~cm})$ at the experimental site. One of them was the recently used and emptied feeder taken from the original feeding site (where the bees had fed ad libitum). This feeder was defined as $\mathrm{M}$ feeder, assumed to be marked by foraging bees. The other feeder was a fresh, alcohol cleaned feeder, defined as U-feeder (unmarked). Both feeders were filled with $3 \mathrm{ML}^{-1}$ unscented sugar water. The experiment started when we placed the $\mathrm{M}$ - and the U-feeder onto the feeding table at the experimental site. It lasted for 20 min during which every bee at the feeders was captured. Again we only counted bees if at the same time no other bee was at the feeder. The feeders' positions were exchanged every five minutes.

Control tests. For (i) and (ii) we performed a control test series to show how many bees find an additional feeding site due to the feeders' visual appearance, but without any chemical signals. Two unused, alcohol cleaned feeders containing $3 \mathrm{ML}^{-1}$ unscented sugar water were presented on an otherwise identical setup. Every bee landing on a feeder was captured and counted.

\subsection{Experiments to demonstrate the precision of food source localization}

Using $0.5-0.75 \mathrm{ML}^{-1}$ unscented sugar water several bees were trained to a feeder mounted on a feeding table in a specific direction and at a specific distance (at $50 \mathrm{~m}$ ) from the nest. We marked one to three bees (foragers) with a colored dot on their thorax. All the other bees were captured using a plastic suction tube and kept in a jar until the end of 
the experiment. After the marked foragers had collected at the training feeder and had returned to their nest three times the training feeder was put away in an airtight plastic dish and replaced by the alcohol cleaned experimental feeder filled with $3 \mathrm{ML}^{-1}$ unscented sugar water. An identical control feeder containing $3 \mathrm{ML}^{-1}$ unscented sugar water was placed on a feeding table in a different direction or at a different distance from the nest, as described by Jarau et al. (2000). The foragers were allowed to feed at the experimental feeder for 2 hours. All the newly recruited bees at both of the feeders were captured, counted, and the time of their arrival noted. The respective distances between the experimental and the control feeder were $1.7 \mathrm{~m}$, $8.5 \mathrm{~m}$, and $17 \mathrm{~m}$ (Fig. 5) depending on the test series.

\subsection{Statistical analyses}

For all statistical procedures SigmaStat 2.0 and SigmaPlot 2000 were used. As the number of bees visiting the feeders varied among the experiments due to environmental factors and the colony's condition, we used the percentage of the total number $(\mathrm{N})$ of bees ( $\mathrm{n}$ at U-feeder $+\mathrm{n}$ at $\mathrm{M}$-feeder $=\mathrm{N}=$ $100 \%)$ to describe the distributions of bees at the feeders. The sample size always was 6 experiments per test series, except for the localization experiments with the control feeder $17 \mathrm{~m}$ in front and $17 \mathrm{~m}$ beyond the experimental feeder, where the sample size was 4 experiments. In the case of a normal distribution (Kolmogorov-Smirnov-test), the data are presented as the mean percentage $( \pm$ SD) of bees, whereas the median percentage (1.quartil/ 3.quartil) of bees is given when the $\mathrm{K}-\mathrm{S}$-test failed. In control experiments the numbers of bees at the A-feeder and at the B-feeder were compared applying the $\chi^{2}$-test. The distribution of bees at the feeders in choice experiments, when bees were choosing the M-feeder, was compared by the Student t-test with the distribution of bees in the control tests when bees were "preferring" the A-feeder among two identical clean feeders. In all the other test series we applied the Student t-test or the $\chi^{2}$-test in case of normally distributed data or, when the equal variance test failed, the Mann Whitney rank sum test. For non-parametric comparisons we used the $\chi^{2}$-test and the Mann Whitney rank sum test.

\section{RESULTS}

\subsection{Behavior at the feeding site}

The time spent by $S$. depilis at a feeder containing $3 \mathrm{ML}^{-1}$ sugar water varied from 1 to 61 seconds $(\mathrm{N}=6 ; \mathrm{n}=292)$. The mean time which each individual bee $(\mathrm{N}=6)$ spent at the feeder varied between $13 \pm 10 \mathrm{~s}$ to $30 \pm 13 \mathrm{~s}$. We noticed a behavior of the foragers, which resembled the "nervous" behavior of Scaptotrigona at the feeding site described by Lindauer and Kerr (1958, 1960). The bees often rapidly changed their feeding behavior from one single food intake per visit to interrupted visits. They stopped drinking after a few seconds to fly up and in a circle around the feeding site (within approx. $1 \mathrm{~m}$ ). Then they landed again at the feeder to drink for another few seconds. This behavior was repeated two to four times. The mean duration of uninterrupted feeding times was $26 \pm 10 \mathrm{~s}(\mathrm{n}=150)$. Each feeding time during interrupted visits lasted for $13 \pm 8 \mathrm{~s}(\mathrm{n}=142)$. The obvious behavior of scent path marking was never observed at the feeders or beyond the feeding site, but could be seen clearly on the bees' way from the feeding site to the nest. When at the feeders the bees did not rub their mandibles on any items nor did they deposit substances visible to the human observer like anal droplets.

\subsection{Chemical marking at the feeding site}

In all the choice experiments the bees strongly preferred the used M-feeder. In most of the control tests, when the bees had to choose between two identical clean feeders, more bees landed on one of them. However, the distributions of bees at the "preferred" control feeder (A-feeder) and at the B-feeder never differed from each other significantly $\left(\chi^{2}\right.$-test, $\left.P \geq 0.05\right)$. When the distance $d$ between the feeders was $20 \mathrm{~cm}, 58.9 \pm 7.7 \%$ of the returning bees chose the A-feeder. When $d$ was $170 \mathrm{~cm}$ a mean percentage of $59.3 \pm 4.2 \%$ landed at the A-feeder (Fig. 2). In all cases the percentage of bees choosing the used M-feeder significantly exceeded the percentage of bees choosing the A-feeder in control tests $(P \leq 0.05)$ (Fig. 2). This is taken as evidence that the bees do mark their feeding site chemically and thereby attract nestmates searching for food.

When the distance between the M-feeder and the U-feeder was $d=20 \mathrm{~cm}$ the percentage of bees at the M-feeder was $75.8 \pm 9.6 \%$, with $0.75 \mathrm{ML}^{-1}$ sugar water. The percentage was 
a

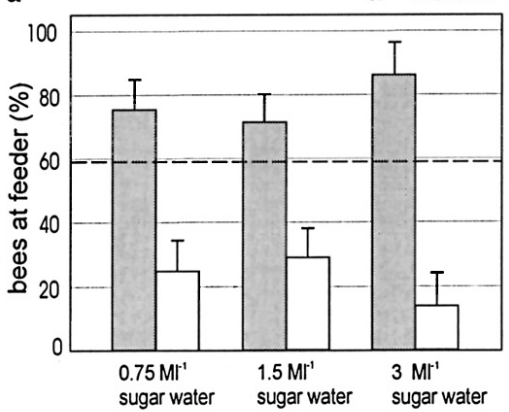

b

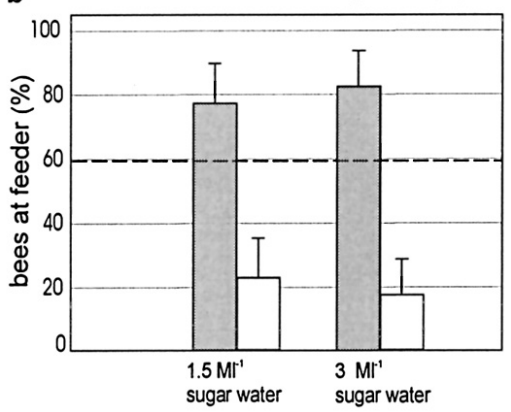

Figure 2. Mean percentage (+ $1 \mathrm{SD})$ of bees landing at the (marked) $\mathrm{M}$-feeder (grey bars) and at the (unmarked) U-feeder (white bars) during choice experiments $(100 \%=$ bees at $\mathrm{M}$-feeder + bees at U-feeder). The dashed line represents the mean percentage of bees in control tests "preferring" one out of two identical clean feeders. In all cases the percentage of bees at the M-feeder significantly exceeded that of the control group $(P \leq 0.05)$. (a) $d=20 \mathrm{~cm}$. The percentage of bees preferring the M-feeder during experiments with $0.75 \mathrm{ML}^{-1}$, $1.5 \mathrm{ML}^{-1}$, and $3 \mathrm{ML}^{-1}$ sugar water, respectively, differed significantly from the percentage of bees at the U-feeder $(P \leq 0.001)$. (b) $d=170 \mathrm{~cm}$. The percentage of bees landing at the M-feeder during experiments with $1.5 \mathrm{ML}^{-1}$ and with $3 \mathrm{ML}^{-1}$ sugar water was significantly higher than the percentage at the $\mathrm{U}$-feeder $(P \leq 0.001)$.

$71.1 \pm 8.9 \%$, when we used $1.5 \mathrm{ML}^{-1}$ sugar water, and $86.1 \pm 10.2 \%$ with $3 \mathrm{ML}^{-1}$ sugar water (Fig. 2a). These values significantly exceed the percentages of the control group $(P \leq 0.05)$. When the distance between M-feeder and U-feeder was $d=170 \mathrm{~cm}$, $77.1 \pm 12.7 \%$ of the returning bees chose the M-feeder containing $1.5 \mathrm{ML}^{-1}$ sugar water. $82.3 \pm 11.4 \%$ of the bees chose it when $3 \mathrm{ML}^{-1}$ sugar water was offered (Fig. 2b).
Again, significantly more bees came to the M-feeder than came to the "preferred" feeder in the control tests $(P \leq 0.01)$.

\subsection{Feeding site marks remain effective when spatially separated from their original site}

The used feeder still attracted bees when it was displaced from the original feeding site. (i) The bees recognized the M-feeder as the goal of their search, when it was positioned halfway along the scent path to the original feeding site together with the unused U-feeder. When the used M-feeder was moved away from its original feeding site at $25 \mathrm{~m}$ to our experimental site at $13 \mathrm{~m}$ from the nest a median number of 10 (4/19) bees alighted during 20 minutes of observation (Fig. 3a). As many as $94.7 \pm 6.8 \%$ of these bees landed on the used M-feeder. This is significantly more than on the clean $U$-feeder $\left(\chi^{2}\right.$-test, $\left.P \leq 0.001\right)$ and underlines the persisting attraction of the used feeder (Fig. 4a). In the control tests using two clean feeders, only the visual appearance, but not chemical cues, could have attracted the bees to the additional feeding site halfway along the scent path (Fig. 3a). No bee, or only one bee, (median $\mathrm{N}=0 ; 0 / 0.75$ ) landed during 20 minutes of observation. The difference in the number of bees landing on the feeders in experiments, which included the M-feeder, and in control tests with two unused feeders is highly significant $(P \leq 0.01)$. (ii) Its chemical markings also attracted the bees when the used M-feeder was $20 \mathrm{~m}$ beyond the original feeding site together with a clean U-feeder. A median number of $7(2 / 12)$ bees appeared within $20 \mathrm{~min}$ of observation (Fig. 3b). Again the mean percentage of bees landing at the M-feeder $(87.9 \pm 12.8 \%)$ significantly exceeded the mean percentage of bees at the U-feeder $\left(\chi^{2}\right.$-test, $\left.P<0.001\right)$ (Fig. $\left.4 b\right)$. In control tests, hardly any bees alighted within 20 min (median $\mathrm{N}=1.5 ; 0 / 4$ ). Again the difference from the number of bees landing in experiments with the used feeder was significant $(P<0.05)$ (Fig. 3b). The efficiency of the attractants did not differ significantly between the test series halfway along and $20 \mathrm{~m}$ beyond the scent path, either in regard to the number of bees alighting at the feeders or in regard to the percentage of bees landing at the 


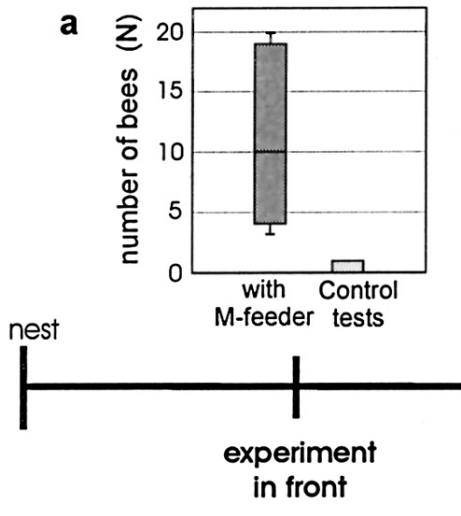

Figure 3. Moving the used M-feeder away from the original feeding site attracted bees to the respective new experimental site. (a) During experiments with the used M-feeder and unused U-feeder at $13 \mathrm{~m}$ from the nest in front of the original feeding site $(25 \mathrm{~m})$ significantly more bees alighted at the feeders (dark bars) than in control tests (light bars) where two unused feeders were presented $(P \leq 0.01)$. (b) $20 \mathrm{~m}$ beyond the original feeding site $(50 \mathrm{~m})$ again significantly more bees appeared at the feeders in experiments with the $\mathrm{M}$-feeder and the U-feeder than during control tests with two clean feeders $(P \leq 0.05)$. The bold line represents the scent path between nest and original feeding site. The dashed line represents the $20 \mathrm{~m}$ gap between the end of the scent path and the experimental site beyond it. The distances between the nest and the original feeding site and the experimental sites are not drawn to scale, because the distances to the original feeding site were different in a $(25 \mathrm{~m})$ and $\mathrm{b}(50 \mathrm{~m})$.

\section{$a$ in front of original site}

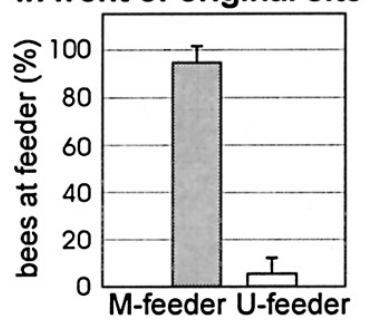

b beyond original site

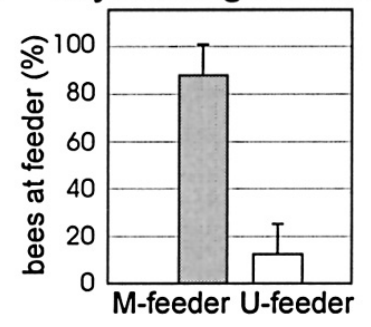

Figure 4. Mean percentage (+ $1 \mathrm{SD})$ of bees landing at the (marked) M-feeder (grey bars) and (unmarked) U-feeder (white bars) when the used M-feeder was moved away from the original to a new feeding site $13 \mathrm{~m}$ in front (a) and $20 \mathrm{~m}$ beyond (b) the original one. The bees strongly preferred the M-feeder $(P \leq 0.001)$ over the U-feeder, indicating that the feeding site markings remained effective at some distance from the feeder's original site.
M-feeder $(P=0.05)$. Hence the markings remained effective regardless of their new position away from their original site. The fact that the bees still recognized the M-feeder as the goal of their search suggests that the markings at the feeder are particular attractants which differ from the scent path markings.

\subsection{Precise localization of the food source}

Of what use could an additional attractant at the food source proper be? Experiments on the precision of food source localization seem to provide an explanation. Foragers of $S$. depilis showed an impressively precise recruitment of their nestmates to the experimental feeder (Fig. 5). Group foraging was occasionally observed. However, in all of the experiments only about $8 \%$ of the arrivals at the feeder were groups of 3-20 bees, whereas all the other recruited bees arrived singly. There was no indication of group effects.

In all our experiments the number of recruits arriving at the used experimental feeder was significantly higher than the number of recruits at the control feeder (both 

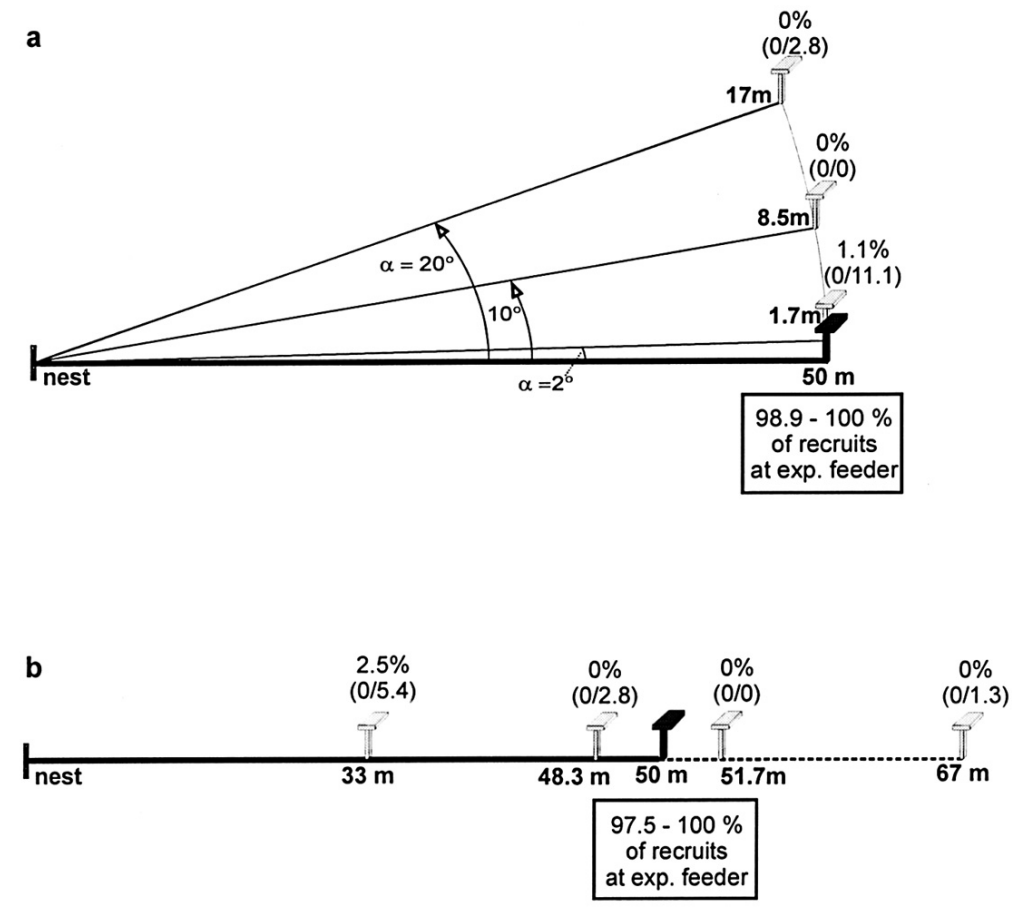

Figure 5. Precision of food source localization. (a) Direction: during these experiments foragers were feeding at the experimental feeder $50 \mathrm{~m}$ (see black table) from the nest and recruiting their nestmates. Control feeders (grey tables) with sugar water of the same concentration were offered $1.7 \mathrm{~m}, 8.5 \mathrm{~m}$, or $17 \mathrm{~m}$ laterally to the experimental feeder at the same distance. The angles $(\alpha)$ between the direction from the nest to the experimental feeder and from the nest to the control feeder were $2^{\circ}, 10^{\circ}$, and $20^{\circ}$, respectively. Recruits nearly exclusively arrived at the experimental feeder (see inset which gives the range of median percentages of bees arriving at the experimental feeder). The median percentage (1.quartil/ 3.quartil) of recruits landing at the control feeders is given above each of the three feeding tables. It was significantly smaller than that at the experimental feeder $(P \leq 0.01)$ in all cases. The bold line indicates the scent path between the nest and the experimental feeder. (b) Distance: here the experimental feeder was $50 \mathrm{~m}$ from the nest. Control feeders were offered at different distances but in the same direction from the nest. The median percentage (1.quartil/3.quartil) of recruits is shown above each control feeding table (see grey tables). In all cases significantly more bees landed at the experimental feeder (see black table) than at the control feeder $(P \leq 0.01)$. Inset: range of median percentages of bees landing at the experimental feeder. The bold line indicates the scent path between the nest and the experimental feeder. The dashed line represents the gap beyond the scent path. The distances between the experimental feeder and the control feeder were $17 \mathrm{~m}$ and $1.7 \mathrm{~m}$, respectively. Note that not a single bee came to the control feeder $1.7 \mathrm{~m}$ beyond the experimental feeder and only one bee to the control feeder $17 \mathrm{~m}$ beyond it.

containing $3 \mathrm{ML}^{-1}$ sugar water) $\left(\chi^{2}\right.$-test, $P \leq 0.01)$. Even when the control feeder was as close as $1.7 \mathrm{~m}$ to the left or to the right of the experimental feeder, and at the same distance of $50 \mathrm{~m}$ from the nest, a median percentage of $98.9(88.9 / 100) \%$ of the recruits landed at the experimental feeder which the foragers were using. Under these conditions the angle $\alpha$ between the direction from the nest to the experimental feeder and to the control feeder measured $2^{\circ}$ only (Fig. 5a). With the control feeder $8.5 \mathrm{~m}\left(\alpha=10^{\circ}\right)$ laterally to the experimental feeder (both $50 \mathrm{~m}$ from the nest) only 3 bees in only one experiment landed on the control feeder and no bees at all in all other experiments. All other recruits (range $=98-$ $100 \%$ ) landed on the experimental feeder. With the control feeder $17 \mathrm{~m}$ to the left or to the right of the experimental feeder $\left(\alpha=20^{\circ}\right)$ a median percentage of $0(0 / 2.8) \%$ of the 
recruits flew to the control feeder and 100 $(97.2 / 100) \%$ found the experimental feeder. This impressively precise localization of the food source with regard to its direction is equalled by the precision with which the bees handled food distance (Fig. 5b). When the control feeder was $33 \mathrm{~m}$ away from the nest along the scent path only $2.5(0 / 5.4) \%$ of the recruits landed on the control feeder, although it was nearer now to the nest than the food source used by their foraging nestmates. As many as $97.5(94.6 / 100) \%$ of the recruits still followed the scent path to its end at $50 \mathrm{~m}$ and landed at the experimental feeder. In the experiments with the control feeder $1.7 \mathrm{~m}$ in front of the experimental feeder (i.e. control feeder nearer to the nest) only twice did a single recruit choose the nearer food source whereas the vast majority of the recruits (range $=94.3-100 \%$ ) landed on the experimental feeder. When the control feeder was $17 \mathrm{~m}$ beyond the experimental feeder, i.e. beyond the scent path, no bee or only one bee (in 1 out of 4 experiments) found the control feeder (median percentage $0 ; 0 / 1.3 \%$ ). The most compelling results were those of the experiments with the control feeder located $1.7 \mathrm{~m}$ behind the experimental feeder. In all of these experiments all $(100 \%)$ of the recruits landed on the experimental feeder, but not a single bee on the control feeder. This impressive precision in food source localization suggests that the markings at the feeding site tag the end point of a bee's foraging trip.

\section{DISCUSSION}

From our results we draw two conclusions. 1. S. depilis scent marks its food source and does this in a way different from the laying of a scent path. 2. These scent marks function as effective attractants, and are interpreted as tags particularly marking the end point of the path to the food source.

\subsection{Chemical markings at the feeding site}

Our choice experiments demonstrated attractant scent marks left at the food source by $S$. depilis which are reminiscent of those recently described in M. seminigra (Hrncir et al., 2003). When comparing the two species, the scent marking of $S$. depilis seems to be more efficient than that of M. seminigra. In the latter species 20 landings of the foragers did not affect the choice of the bees between the marked and the unmarked feeder. In contrast to $S$. depilis at least 30 landings by the foragers were necessary to attract recruits to the used (and marked) feeder. In S. depilis the percentage of bees choosing the marked feeder after 20 forager landings (71 to $86 \%$ ) always exceeded the percentage found for $M$. seminigra, even after as many as 200 landings ( $d=20 \mathrm{~cm} ; 68 \%)$.

Our results also bring to mind attractants left at food sources by bumblebees and honeybees (Butler et al., 1969; Ferguson and Free, 1979; Schmitt and Bertsch, 1990; Schmitt et al., 1991). In these cases the attractants are "footprint" substances, secreted at the bees' tarsi. In stingless bees attractants on the feeding site itself were studied by Aguilar and Sommeijer (1996, 2001). They suggested that anal droplets serve as chemical cues for foraging Melipona favosa. Nieh (1998) tested attractants at the feeding site in M. panamica, but the source of the scent beacon remained unclear. Hrncir et al. (2003) excluded the possibility of anal droplets for M. seminigra and showed that instead "footprint" substances are the relevant signals. Our present work did not aim at the identification of the scent marks' origin. However, our experiments do exclude (i) the deposition of attractant substances into the sugar water itself (we changed the sugar water when moving the M-feeder away from the original feeding site) and (ii) the involvement of anal droplets which were not deposited by $S$. depilis.

According to Lindauer and Kerr (1958) foragers of Scaptotrigona postica started scent marking near the feeding site and on their way back to the nest (scent path) after only 11 visits to the food source. In our choice experiments four foragers fed at the food source until they completed a total of 20 visits which amounts to an average of five visits per bee. In no case did the number of visits per bee exceed 9 . We conclude that the bees started to mark the food source right after its discovery. 


\subsection{Particular attractants differing from scent path marks}

In $S$. depilis the feeding site marks at the $\mathrm{M}$-feeder remained attractive even when presented both halfway along the scent path or as much as $20 \mathrm{~m}$ beyond the end of the scent path and thus far away from the original feeding site. We interpret our findings to imply that the used feeder had been marked with specific attractants representing the end point of the scent path. Even when displaced from their original site these marks retained this function.

Lindauer and Kerr (1958, 1960) demonstrated the necessity of the scent path for successful recruitment in Scaptotrigona by training foragers along a lake's shore. When flying from the feeding site to the nest over a body of water the foragers could not lay a scent path. Accordingly, no recruits came to the feeding site. The lack of a scent path over a length of approximately $20 \mathrm{~m}$ made it impossible for recruits to find the feeding site. Our own displacement experiments demonstrated that the M-feeder (already used and obviously marked by the foragers) attracted the bees even when it was $20 \mathrm{~m}$ beyond the original feeding site and thus $20 \mathrm{~m}$ away from the scent path. Such high attraction can hardly be explained by scent path marks, even less so, as the foragers never showed the behavior typical of scent path marking at the feeder or beyond the original feeding site.

Further evidence for the existence of particular feeding site marks comes from our localization experiments and the remarkable precision with which $S$. depilis finds a food source (Fig. 5). When the control feeder was placed $1.7 \mathrm{~m}$ beyond the used feeder not a single bee landed on the control feeder. Our results suggest that the marks left at the feeding site serve as end point tags, which are hardly ever surpassed by newly recruited bees.

Natural food sources are more scattered than the food sources offered in our experiments. Obviously, ignoring still unvisited flowers near the flowers already exploited would be of little use for a colony. Such behavior is indeed unlikely to occur because the scent of flowers is an important cue in the communication between the forager and its recruits (Lindauer, 1956; Lindauer and Kerr, 1960; Biesmeijer and Ermers, 1999). In order to exclude this kind of communication only unscented food was presented in the present study. In both Trigona carbonaria (Nieh et al., 2000) and in Melipona seminigra (Hrncir et al., 2003) it has been suggested that active chemical marking of the feeding site is of greater importance on unscented food sources than on scented food sources.

\subsection{Ecology of foraging strategies}

The remarkably precise localization of a food source in scent path laying stingless bees, as shown by several authors (Lindauer and Kerr, 1958, 1960; Kerr et al., 1963; Hubbel and Johnson, 1978) and confirmed by our present work, seems to contrast with less precise localization of food sources in non-scent path laying bees of the genus Melipona (Lindauer and Kerr, 1958, 1960; Kerr et al., 1963; Nieh and Roubik, 1995; Nieh and Roubik, 1998; Jarau et al., 2000). In Melipona sp. the majority of recruits chooses the food source nearest to the nest, be it the used experimental feeder or the unused control feeder (Jarau et al., 2000). The strategy of an initial random search employed by Melipona species (Jarau et al., 2000, 2003) increases their foraging success, and non-scent trail laying species may encounter many food sources in a very short time (Jarau et al., 2003; Slaa et al., 1997). In honeybees various adaptations to environmental conditions are known (e.g. von Frisch, 1967). When resources are plentiful and arrayed in small patches the recruitment system is less precise (i.e. recruits follow fewer dances and their orientation is less focused) than when the resources are scarce. In the latter case the precision of the recruitment system is highly important for the colony's food acquisition (Visscher and Seeley, 1982; Seeley and Visscher, 1988; Seeley et al. 1991, Waddington et al., 1994). Scent trail laying stingless bees, on the other hand, seem to be particularly good at the exact localization of a food source and its exploitation until it is depleted (Hubbel and Johnson, 1978). Furthermore, scent trail recruitment facilitates group foraging, which enables bees to monopolize dense patches of highly rewarding resources with sufficient food for many bees (Johnson and Hubbel, 1975; Hassel and Southwood, 1978; Hubbel and Johnson, 1978). According 
to Jarau et al. (2003), up to 1682 recruits of $S$. depilis came within 4 hours to exploit a single artificial food source such as those used in our study. As expected from the difference in foraging strategies, the marks left by $S$. depilis at the feeding site are more attractive than those of M. seminigra (Hrncir et al., 2003). In our experiments $S$. depilis followed its scent path and perceived the marks left at the feeder as the end point of the foraging trip.

\section{ACKNOWLEDGEMENTS}

We would like to thank Michael Hrncir, Stefan Jarau, and Sidnei Mateus for their unfailing help and support. We are grateful to Professor J.F.M. de Camargo for his comments on bee taxanomy. This work was supported by a grant of the Austrian Science Foundation to FGB (P 14328) and by a grant from the BMBWK of Austria to VMS.

Résumé - Une abeille sans aiguillon (Scaptotrigona aff. depilis) marque la source de nourriture en plus de la piste odorante. De nombreuses espèces d'abeilles sans aiguillon laissent une piste odorante pour indiquer le chemin d'une source de nourriture (Lindauer et Kerr, 1958). Jusqu'à présent on ignore si le marquage odorant des pistes constitue le seul indicateur chimique utilisé par les abeilles pour trouver des sources de nourriture. Nous montrons ici que Scaptotrigona aff. depilis (Apidae, Meliponinae) Moure 1942 dépose une piste odorante mais laisse en outre un marquage chimique à la source de nourriture. Lorsque des abeilles en quête de nourriture ont le choix, à une source de nourriture connue, entre un nourrisseur $\mathrm{M}$ auquel des membres de la colonie ont déjà butiné, et un nourrisseur U identique mais inutilisé (Fig. 1), 71 à $86 \%$ d'entre elles choisissent le nourrisseur M. Visiblement les abeilles qui avaient butiné au nourrisseur M l'avaient marqué avec des substances attractives (Fig. 2). On suppose que ces substances se différencient de celles de la piste odorante car les abeilles présentes sur le nourrisseur ne montraient jamais le comportement typique du dépôt de piste odorante. En outre les marquages à la source de nourriture par les abeilles en quête de nourriture ont été reconnus même lorsque le nourrisseur utilisé avait été déplacé de l'endroit d'origine (Figs. 3 et 4). La question se pose de savoir quelle fonction possède ce marquage supplémentaire. Pour cela nous avons fait des expériences dans lesquelles une à trois abeilles butinaient à un nourrisseur $\mathrm{M}$ éloigné de $50 \mathrm{~m}$ du nid et recrutaient des membres de la colonie. Des nourrisseurs identiques placés soit dans une autre direction soit à une autre distance servaient de témoin (nourrisseur U). Durant les deux heures d'observation toutes les nouvelles arrivantes (recrues) ont été capturées et comptées aussi bien sur le nourrisseur $\mathrm{M}$ que sur le $\mathrm{U}$. Les recrues trouvaient toujours presque toutes (98$100 \%$ ) avec une précision impressionnante le nourrisseur $M$ où s'étaient abreuvées les butineuses (Fig. 5). Par contre il n'y avait que très peu ou pas du tout d'abeilles sur les nourrisseurs U qui étaient éloignés latéralement de $1,7 \mathrm{~m}, 8,5 \mathrm{~m}$ ou $17 \mathrm{~m}$. Même lorsque le nourrisseur U était plus près du nid que le nourrisseur $\mathrm{M}$ de $1,7 \mathrm{~m}$ ou $17 \mathrm{~m}$, seulement 0 à $2,5 \%$ des abeilles atterrissaient sur le nourrisseur U. De toute évidence les marquages chimiques au nourrisseur sont reconnus par les abeilles comme point d'arrivée de leur quête de nourriture. Comparée à Melipona seminigra, qui ne dépose pas de piste odorante mais laisse des marquages semblables à la source de nourriture (Hrncir et al., 2003), l'attractivité des marquages est plus forte chez $S$. depilis. Cela se voit par le nombre de visites nécessaires pour un marquage efficace ( $M$. seminigra $>$ $30 ;$ S. depilis $<20$ ).

\section{Scaptotrigona / abeilles sans aiguillon / mar- quage odorant / recrutement}

\section{Zusammenfassung - Eine stachellose Biene mar-} kiert die Futterstelle zusätzlich zum Duftpfad (Scaptotrigona aff. depilis). Viele Arten von stachellosen Bienen legen Duftpfade als Wegweiser zu Futterquellen (Lindauer und Kerr, 1958). Ob diese Duftpfadmarken die einzigen chemischen Wegweiser bei der Nahrungssuche dieser Bienen sind, ist bisher nicht bekannt. In der vorliegenden Arbeit wird gezeigt, dass die einen Duftpfad legende Biene Scaptotrigona aff. depilis Moure 1942 an ihrer Futterstelle zusätzliche chemische Markierungen hinterlässt. Wenn die futtersuchenden Bienen an einer schon bekannten Futterstelle die Wahl zwischen einem Futterschälchen hatten, an dem ihre Nestgenossinnen bereits getrunken hatten, und einem identischen unbenutzten Futterschälchen (Abb. 1), dann wählten 71 bis $86 \%$ von ihnen das erstere. Offensichtlich hatten die zuvor am Futterschälchen trinkenden Bienen dieses mit attraktiven Substanzen markiert (Abb. 2). Diese Substanzen unterscheiden sich vermutlich von denen des Duftpfades: An der Futterstelle zeigten die Bienen niemals ihr für das Legen des Duftpfades typisches Verhalten. Weiterhin konnten die Markierungen am Futterschälchen von den futtersuchenden Bienen auch dann erkannt werden, wenn das benutzte Futterschälchen sich nicht mehr am ursprünglichen Ort befand (Abb. 3, Abb. 4). Es stellt sich die Frage, welche Funktion eine zusätzliche Markierung der Futterstelle hat. Dazu führten wir Experimente durch, in welchen ein bis drei Bienen an einem Futterschälchen $50 \mathrm{~m}$ vom Nest entfernt sammelten und ihre Nestgenossinnen rekrutierten. Zur Kontrolle befanden sich identische Futterquellen entweder in einer anderen Richtung oder einer anderen Entfernung vom Nest. Während 
der zweistündigen Beobachtungszeit wurden alle neuankommenden Bienen (Rekruten) sowohl am benutzten Futterschälchen als auch am KontrollFutterschälchen gefangen und gezählt. Stets fanden fast alle Rekruten (98-100 \%) mit beeindruckender Genauigkeit das Futterschälchen, an dem die Sammelbienen tranken (Abb. 5). Dagegen flogen nur wenige oder gar keine Bienen zu den unbenutzten Futterschälchen, die 1,7 m, 8,5 m bzw. $17 \mathrm{~m}$ seitlich davon entfernt standen. Auch wenn das KontrollFutterschälchen 1,7 m bzw. $17 \mathrm{~m}$ näher am Nest stand als das benutzte Futterschälchen, landeten nur 0-2,5\% der Bienen an diesem. Bei einer Position des Kontroll-Futterschälchens jenseits des bereits benutzten Futterschälchens besuchten die Bienen ausschließlich letztere. Die chemischen Markierungen am Futterschälchen werden von den Bienen offensichtlich als Endpunkt ihrer Futtersuche erkannt. Im Vergleich zu Melipona seminigra, die keine Duftpfade legt, aber ähnliche Markierungen an der Futterstelle hinterlässt (Hrncir et al., 2003), ist die Attraktivität der Markierungen bei $S$. depilis stärker. Dies folgt aus der Zahl der Bienenbesuche, die für eine effektive Markierung erforderlich sind (M. seminigra $>30$, S. depilis $<20$ ).

\section{Stachellose Biene / Scaptotrigona / Duftpfade / Rekrutierung}

\section{REFERENCES}

Aguilar I., Sommeijer M.J. (1996) Communication in stingless bees: Are the anal substances deposited by Melipona favosa scent marks? Proc. Exp. Appl. Entomol., N.E.V. Amsterdam 7, 57-63.

Aguilar I., Sommeijer M.J. (2001) The deposition of anal excretions by Melipona favosa foragers (Apidae: Meliponinae): behavioural observations concerning the location of the food sources, Apidologie 32, 37-48.

Biesmeijer J.C., Ermers C.W. (1999) Social foraging in stingless bees: how colonies of Melipona fasciata choose among nectar sources, Behav. Ecol. Sociobiol. 46, 129-140.

Blum M.S., Crewe R.M., Kerr W.E., Keith L.H., Garrisson A.W., Walker M.M. (1970) Citral in stingless bees: isolation and function in traillaying and robbing, J. Insect Physiol. 16, 16371648.

Butler C.G., Fletcher D.J.C., Walter D. (1969) Nestentrance marking with pheromones by the honeybee, Apis mellifera L., and by the wasp, Vespula vulgaris L., Anim. Behav. 17, 142-147.

Cruz-Landim C. da, Akahira Y. (1966) Influência da alimentação no desenvolvimento de algumas glândulas de Trigona (Scaptotrigona) postica Latreille (Hymenoptera - Apoidea), Pap. Avulsos Dep. Zool. (São Paulo) 19, 63-78.

Cruz-Landim C. da, Ferreira A. (1967) Capacidade de comunicação e grau de desenvolmimento das glândulas mandibulares de Trigona (Scaptotrigona) postica Latreille, Ciência e Cultura 19, 268.

Cruz-Landim C. da, Ferreira A. (1968) Mandibular gland development and communication in field bees of Trigona (Scaptotrigona) postica, J. Kans. Entomol. Soc. 41, 474-481.

Ferguson A.W., Free J.B. (1979) Production of a forage-marking pheromone by the honeybee, $\mathrm{J}$. Apic. Res. 18, 128-135.

Francke W., Schröder W., Engels W., Engels E., (1983) Variation in cephalic volatile substances in relation to worker age and behaviour in the stingless bee, Scaptotrigona postica, $\mathrm{Z}$. Naturforsch. 38c, 1066-1068.

Frisch K. von (1967) The dance language and orientation of bees, Harvard Univ. Press, USA.

Hassel M.P., Southwood T.R.E. (1978) Foraging strategies of insects, Annu. Rev. Ecol. Syst. 9, $75-98$.

Hrncir M., Jarau S., Zucchi R., Barth F.G. (2000) Recruitment behavior in stingless bees, Melipona scutellaris and M. quadrifasciata. II. Possible mechanisms of communication, Apidologie 31, 93-113.

Hrncir M., Jarau S., Zucchi R., Barth F.G. (2003) On the origin and properties of scent marks deposited at the food source by a stingless bee, Melipona seminigra Friese 1903, Apidologie, accepted.

Hubbel S.P., Johnson L.K. (1978) Comparative foraging behavior of six stingless bee species exploiting a standardized resource, Ecology 59, 1123-1136.

Jarau S., Hrncir M., Zucchi R., Barth F.G. (2000) Recruitment behavior in stingless bees, Melipona scutellaris and $M$. quadrifasciata. I. Foraging at food sources differing in direction and distance, Apidologie 31, 81-91.

Jarau S., Hrncir M., Schmidt V.M., Zucchi R., Barth F.G. (2003) Effectiveness of recruitment behavior in stingless bees (Apidae, Meliponini), Insectes Soc., accepted.

Johnson L.K. (1987) Communication of food source location by the stingless bee Trigona fulviventris, in: Eder J., Rembold H. (Eds.), Chemistry and biology of social insects, Verlag J. Peperny, München, pp. 698-699.

Johnson L.K., Hubbel S.P. (1975) Contrasting foraging strategies and coexistence of two bee species on a single resource, Ecology 56, 13981406.

Kerr W.E. (1960) Evolution of communication in bees and its role in speciation, Evolution 14, 386387.

Kerr W.E. (1994) Communication among Melipona workers (Hymenoptera: Apidae), J. Insect Behav. 7, 123-128.

Kerr W.E., Cruz da C. (1961) Funções diferentes tomadas pela glândula mandibular na evolução das abelhas e em Trigona (Oxytrigona) tataira em especial, Rev. Bras. Biol. 21, 1-16. 
Kerr W.E., Blum M.S., Fales H.M. (1981) Communication of food sources between workers in Trigona (Trigona) spinipes, Rev. Bras. Biol. 41, 619-623.

Kerr W.E., Ferreira A., de Mattos N.S. (1963) Communication among stingless bees additional data (Hymenoptera: Apidae), J. N.Y. Entomol. Soc. 71, 80-90.

Lindauer M. (1956) Über die Verständigung bei indischen Bienen, Z. Vergl. Physiol. 38, 521557.

Lindauer M., Kerr W.E. (1958) Die gegenseitige Verständigung bei den stachellosen Bienen, Z. Vergl. Physiol. 41, 405-434.

Lindauer M., Kerr W.E. (1960) Communication between the workers of stingless bees, Bee World 41, 29-41; 65-71.

Luby J.M., Regenier F.E., Clarke E.C., Weaver E.C., Weaver N. (1973) Volatile cephalic substances of the stingless bees, Trigona mexicana and Trigona pectoralis, J. Insect Physiol. 19, 1111-1127.

Nedel J.O. (1960) Morphologie und Physiologie der Mandibeldrüse einiger Bienen-Arten (Apidae), Z. Morphol. Ökol. Tiere 49, 139-183.

Nieh J.C. (1998) The role of a scent beacon in the communication of food location by the stingless bee, Melipona panamica, Behav. Ecol. Sociobiol. 43, 47-58.

Nieh J.C., Roubik D.W. (1995) A stingless bee (Melipona panamica) indicates food location without using a scent trail, Behav. Ecol. Sociobiol. 37, 63-70.

Nieh J.C., Roubik D.W. (1998) Potential mechanisms for the communication of height and distance by a stingless bee, Melipona panamica, Behav. Ecol. Sociobiol. 43, 387-399.

Nieh J.C., Tautz J., Späthe J., Bartareau T. (2000) The communication of food location by a primitive stingless bee, Trigona carbonaria, Zoology 102, 238-246.

Schmitt U., Bertsch A. (1990) Do foraging bumblebees scent-mark a food source and does it matter? Oecologia 82, 137-144.

Schmitt U., Lübke G., Francke W. (1991) Tarsal secretion marks food sources in bumblebees (Hymenoptera: Apidae), Chemoecology 2, 3540.

Seeley T.D., Visscher P.K (1988) Assessing the benefits of cooperation in honeybee foraging: search costs, forage quality, and competitive ability, Behav. Ecol. Sociobiol. 22, 229-237.

Seeley T.D., Camazine S., Sneyd J. (1991) Collective decision-making in honey bees: how colonies choose among nectar sources, Behav. Ecol. Sociobiol. 28, 277-290.

Slaa E.J., Nieuwstadt van M.G.L., Pisa L.W., Sommeijer M.J. (1997) Foraging strategies of stingless bees (Apidae, Meliponinae): the relation between precision of recruitment, competition and communication, Acta Hortic. 437, 193-197.

Visscher P.K., Seeley T.D. (1982) Foraging strategy of honeybee colonies in a temperate deciduous forest, Ecology 63, 1790-1801.

Waddington K.D., Visscher P.K., Herbert T.J., Raveret-Richter M. (1994) Comparison of forager distributions from matched honey bee colonies in suburban environments, Behav. Ecol. Sociobiol. 35, 423-429. 